\title{
A New Species of Modocia (Trilobita: Ptychoparioidea) in the Late Middle Cambrian (Guzhangian: Miaolingian) Devoncourt Limestone, Northwestern Queensland
}

\author{
Peter A. Jell ${ }^{1}$
}

\begin{abstract}
A new species of late middle Cambrian (Guzhangian: Miaolingian) ptychoparioid trilobite is described from the Devoncourt Limestone just west of the Burke River crossing on the Duchess to Cloncurry Road. This is an addition to the extensive study of the fossil fauna of that district in the Burke River Structural Belt and provides another link to the Georgina Basin fauna, albeit younger by one zone, about $200 \mathrm{~km}$ west on Mungerebar Station. Generic assignment of the new species is discussed in relation to a worldwide complex of similar solenopleurid genera with small eyes situated well forward on the cephalon. Some comments are made in relation to family placement of the species, but the question of family concepts relies heavily on revision of an extensive northern hemisphere literature on these standard trilobites; so, although placement in the Solenopleuridae is favoured, no formal family assignment is made until family groups in this large complex of genera are better defined.
\end{abstract}

Keywords: Trilobite, Solenopleuridae, Modocia, Devoncourt Limestone, Burke River Structural Belt, Lejopyge laevigata Zone.

${ }^{1}$ School of Earth Sciences, The University of Queensland, St Lucia, QLD 4072, and Queensland Museum, PO Box 3300, South Brisbane, QLD 4101, Australia (amjell@bigpond.com)

Jell, P. A. (2021). A new species of Modocia (Trilobita: Ptychoparioidea) in the late middle Cambrian (Guzhangian: Miaolingian) Devoncourt Limestone, Northwestern Queensland. Proceedings of The Royal Society of Queensland, 129, x-xx. https://doi.org/10.53060/ prsq.2021.1

https://zoobank.org/43279A92-381A-47B6-934B-EA3F8306704E

\section{Introduction}

The geology of northwestern Queensland has been studied extensively, primarily the Precambrian mineral field, but when regional studies of northern Australia began after the Second World War, the onlapping sedimentary successions also came in for close scrutiny. In the late 1940s the Commonwealth Bureau of Mineral Resources (BMR) began detailed mapping in the region, including the Duchess 1:250,000 map sheet that covers the headwaters of the Burke River. Armin Alexander Öpik, formerly Professor of Geology in the University of Tartu, Estonia, came to Australia as a displaced person at the end of World War II and upon appointment to the BMR began the study of the Cambrian biostratigraphy of northwestern Queensland in 1948. This would occupy the rest of his academic career.

Trilobite-dominated, Cambrian faunas from the northern part of the Burke River Structural Belt in northwestern Queensland were described by Öpik (1961), who also elucidated the geological succession of the area. Öpik's (1961) bulletin on Cambrian faunas from the headwaters of the Burke River was a classic for its time, and he remarked on the similarity of the trilobites to those found in Scandinavia. However, he did not describe

This work is licensed under a Creative Commons Attribution-NonCommercial-NoDerivatives 4.0 International Licence. Individual articles may be copied or downloaded for private, scholarly and not-for-profit use. Quotations may be extracted provided that the author and The Royal Society of Queensland are acknowledged. Queries regarding republication of papers, or parts of papers such as figures and photographs, should be addressed to the Secretary of The Royal Society of Queensland (rsocqld@gmail.com). 
a distinctive, small-eyed trilobite subsequently collected from the Devoncourt Limestone beside the Duchess to Malbon Road. In this paper I describe the new species, discuss its affinities with other similar trilobites described by Öpik (1967) from the Georgina Basin near the Queensland/Northern Territory border, and discuss possible relationships with other closely similar trilobites from elsewhere in the world. Comprehensive knowledge of the regional fossil fauna and biostratigraphy aids the search for minerals: The Burke River Structural Belt has proven phosphate reserves being mined at The Monument, south of Duchess, and is an exploration target for rare earth minerals.

\section{Geological Setting and Age}

All the figured material is from Queensland Museum Locality 1407 at $21^{\circ} 21^{\prime} 53^{\prime \prime} \mathrm{S}, 139^{\circ} 59^{\prime}$ $20^{\prime \prime} \mathrm{E}$, beside the Duchess to Cloncurry Road in the last creek before crossing the Burke River, between Opik's (1961: fig. 2) localities D17A and D15 in the Devoncourt Limestone. Fossils are scarce in the flaggy limestones at this site, and about two hours' collecting produced only single specimens of the bradoriid Aristaluta gutta Öpik, 1961 (Figure 1A) and trilobite Amphoton bensoni Öpik, 1961 (Figure 1B). Both these species occur in the lower part of the Devoncourt Limestone (Öpik, 1961: fig. 15) allowing the collecting site to be placed in the early Lejopyge laevigata Zone, i.e. early Boomerangian Stage in the Australian scheme and internationally in the early Guzhangian (Peng et al., 2009; Geyer, 2019). This horizon may be correlated with Westergård's $(1946,1953)$ Solenopleura brachymetopa Zone in Sweden.

\section{Systematics}

The figured material is catalogued in the fossil collection of the Queensland Museum, Brisbane (QMF). Description of features in the sagittal [sag.] (or exsagittal) axis are described in terms of length, and features described in the transverse axis are described in terms of width.

\section{Order PTYCHOPARIIDA Swinnerton, 1915 Suborder PTYCHOPARIINA Richter, 1933}

Remarks. Fortey (1997) emphasised the identification problems of members of this suborder having such a generalised trilobite morphology - notably, where the absence of distinctive characters has led to stratigraphical and geographical criteria in the taxonomy. The result has been a proliferation of unresolved synonymous taxa. As with many other trilobite taxa, further problems also occur in defining a diagnosis for a species represented by variable morphologies of its holaspid growth stages (Fletcher, 2005).

\section{Superfamily PTYCHOPARIOIDEA Matthew, 1888}

Diagnosis. See "PTYCHOPARIACEA Matthew, $1888 "$.

\section{Family SOLENOPLEURIDAE Angelin, 1854}

Diagnosis. Ptychoparioidea with a rather gibbous, tapering forward, rounded anterior glabella with relatively faint, short, lateral glabellar furrows; occipital ring with median node or spine; a convex preglabellar field, upstanding anterior border; anterior facial sutures inclined inward; small- to medium-size eyes [palpebral lobes] slightly forward of cephalic midpoint; eye ridges faint or absent.

Remarks. This family is based upon the type species of the nominal genus, Solenopleura holometopa (Angelin, 1851-1878) from the Swedish S. brachymetopa Zone; lectotype figured by Westergård 1953, pl. 4, figs 2a, 2b). In contrast, the Ptychopariidae is based upon the type species of its nominal genus, Ptychoparia striata (Emmrich, 1839) characterised by a less-swollen glabella tapering to a truncate anterior preglabellar furrow; "neotype" figured by Šnajdr 1958, p. 186, pl. 38, fig. 19.

Genus Modocia Walcott, 1924

Type species. Arionellus (Crepicephalus) oweni Meek \& Hayden, 1861 from the upper Cambrian Deadwood Formation of South Dakota; by original designation.

Diagnosis. Updated from Walcott (1924, 1925), Lochman-Balk in Harrington et al. (1959) and Robison (1964). Cephalon semicircular, with evenly curved anterior margin, moderate to high convexity with steep downslope to anterior and straight posterior margin. Glabella with moderately converging lateral margins, anteriorly rounded, moderately to highly convex; glabellar furrows 
very shallow (commonly absent in internal mould). Anterior border and occipital ring upstanding, marked by well-impressed furrows. Occipital ring with or without node. Palpebral lobes short, at or just forward of cephalic mid-length; ocular ridges obsolete to distinct. Anterior branches of facial suture subparallel to convergent (up to $20^{\circ}$ to sagittal line), posterior branches gently sigmoid, cutting posterior margin just inside the genal angles. Genal angles rounded or quite angulated, with or without genal spines, which usually are short and make an angle with cheek outline, but may be stout and continue the margin smoothly. Thorax of 12-14 segments, pleural furrow well impressed, pleural tips rounded or weakly spinose. Pygidium with axis of up to six rings plus terminus; pleurae with wellimpressed pleural furrows; interpleural furrows distinct but weak; border poorly defined, if at all.

Remarks. Family assignment of Modocia Walcott, 1924 has been uneasy throughout its history. Even before this generic name was introduced, the species designated as type had had six different generic assignments (see synonymy list in Walcott, 1925, p. 106), though all those names implied that the type species was a solenopleurid (see Fletcher, 2017, p. 179). Walcott $(1924,1925)$ introduced the generic name but did not assign it at family level. Palmer (1954) dealt with Modocia in the section headed "FAMILY UNKNOWN". Lochman \& Duncan (1944) similarly treated Modocia under the heading "INCERTAE SEDIS". Lochman-Balk (in Harrington et al., 1959) gathered a group of disparate genera, including Modocia, into the Marjumiidae, albeit in an exercise in which family arrangement was a high priority, though not mandatory. Rasetti (1963) and Robison (1964) were both highly critical of the family arrangement of ptychoparioid trilobites in the Treatise on Invertebrate Paleontology (Harrington et al., 1959), and whereas the former described the Quebec ptychopariods (including Modocia) without family assignment, the latter maintained Modocia in the Marjumiidae with a group of genera he considered could be shown to be related to Marjumia. Rasetti (1965) discussed Modocia under the heading "PTYCHOPARIIDA of uncertain affinities", while Robison (1988), Sundberg (1996), Robison \& Babcock (2011) and other recent authors have maintained Modocia in the Marjumiidae.

Öpik's (1967) placement of Modocia in the
Solenopleuridae appears to have gone unnoticed except for the mention by Cooper et al. (1990). No North American or European authors have mentioned Öpik's suggestion, and moreover, very few comparisons of Laurentian vs Acado-Baltic genera or species of the Ptychopariida, particularly Solenopleuridae/Ptychopariidae, have entered the literature. Rushton (1978) describing Modocia anglica from the Agnostus pisiformis Zone in Shropshire, England, and Rushton \& Berg-Madsen (2002) in discussing Agaso are exceptions. Most North American authors appear to confine comparisons to the one biogeographical, Laurentian Faunal Province when dealing with these very standard ptychoparioid genera. It must be emphasised that Öpik's (1967) assignment of immodulata to Modocia was by way of direct comparison with the type species which has small eyes situated well forward and anterior facial sutures converging forward of the palpebral lobes - features not shared with numerous species that are at present placed in Modocia and have long eyes situated well posteriorly and facial sutures diverging forward.

In diagnosing the Marjumiidae, Robison (1964, 1988) properly emphasised axial structures and temporal and geographical factors such that members can be demonstrated to belong in an evolutionary lineage that includes the nominate genus. However, due to the very basic axial structure of Marjumia Walcott, 1916 as a standard trilobite, many solenopleurid/ptychoparioid genera from many parts of the world can be accommodated within Robison's morphological diagnosis of the family, including for example not only Solenopleura Angelin, 1854, Parasolenopleura Westergård, 1953, Brunswickia Howell, 1937, Braintreella Wheeler, 1942 and Jincella Šnajdr, 1957 from the Acado-Baltic Province, but also genera from Siberia (Fletcher, 2007, fig. 7), China, and other parts of the world. It must be concluded that inclusion into the family relied heavily on temporal and geographical factors. While this approach is commendable and advocated by numerous authors, e.g. Rasetti, 1948, 1972, there are many examples of virtually worldwide distribution and extra-provincial occurrences of a wide variety of Cambrian trilobites. Indeed, Modocia anglica Rushton, 1978 and Modocia immodulata Öpik, 1967 are such pertinent examples, as noted by Fortey (1997, p. O296). Should they be excluded 
from Modocia because of their geographic (but not temporal) remoteness from the Laurentian province where most species of Modocia occur? Rushton (1978, p. 250) discussed his identification of three polymerid trilobites from England as exotic to the European fauna and noted the exotic occurrence of East Gondwanan Drepanura in Sweden. Surely these examples and numerous others in the literature provide strong evidence to negate geography as a stand-alone family discriminator and heighten the need for better morphological family definition or, if that is not possible, broader family boundaries that are recognisable.

Until that is achieved, I share the uncertainties of earlier authors who were not prepared to assign Modocia to any existing family but here follow Öpik and Kobayashi in recognising the presence of Australian solenopleurids. It may well be the basal member of the Marjumidae in North America as suggested by Sundberg (1996), but its relationships, particularly to contemporary solenopleurids to which its type species bears close resemblance, remain unexplored. Whether there are such relationships, what they may be and what implications they have for family boundaries are beyond the scope of this paper.

The new Australian species described below is tentatively assigned to Modocia Walcott, 1924 by comparison with the type species and a return to Walcott's $(1924,1925)$ original diagnosis and by recognising the validity of Öpik's (1967) comparison of his M. immodulata with M.oweni. While it is not the intention in this paper to review the Laurentian content of Modocia, it is important to note that the Australian species are both placed by comparison with the type species and not by comparison with those several other North American species assigned to Modocia that have long eyes set posteriorly and close to the axis. Walcott (1925, p. 105) erected Modocia for species distinguished by: "The cranidium, however, differs in the direction of the facial sutures through the frontal border and the very broad fixed cheeks." Both Australian species, immodulata and priva, have:

(1) the facial sutures running directly forward or gently converging from the anterior of the palpebral lobe to the border and then turning sharply across the border at a low angle to the margin; and
(2) fixigenae equal to half the glabellar width at midlength of eye, i.e. the same proportion as in M. oweni.

Glabellar shape, short inconspicuous palpebral lobes situated well forward, very weakly impressed glabellar furrows, convex preglabellar field with an anterior border of the same length and overall proportions of the cranidia match extremely closely. As mentioned above, the Australian species match the type much more closely than several North American "marjumiid-like" species assigned to the genus that have anteriorly diverging facial sutures, long posteriorly situated palpebral lobes defined by well-impressed palpebral furrows.

Discrimination of northern hemisphere middleupper Cambrian solenopleurid/ptychopariid genera remains unresolved and subject to a variety of different approaches from different authors. Attaining agreed generic concepts in this complex is outside the scope of the current paper, so the new species is assigned to Modocia based on its close comparison, discussed below, with M. immodulata Öpik, 1967, the geographically and temporally closest solenopleurid species.

Modocia priva sp. nov. (Figures 1,2)

https://zoobank.org/E26F04ED-499E-4808-95263B01D550FF31

Material. Holotype, QMF59832, a dorsal exoskeleton, except for the missing left librigena; paratypes QMF59831-59838, all from QML1407, detailed above.

Etymology. privus, Latin, meaning 'alone, each or single' and referring to the rarity of any accompanying fauna.

Diagnosis. Member of Modocia with moderately convex cephalon, sloping slightly more steeply forward than laterally. Glabella anteriorly rounded, moderately convex; glabellar furrows barely perceptible (Figure 1J). Occipital ring with small central node (Figure 1I). Palpebral lobes short, at or just forward of cephalic mid-length, narrow, gently upturned laterally; ocular ridges low, indistinct (Figure 1J). Anterior branches of facial suture convergent at about $15^{\circ}$ to sagittal line. Genal angles with short, sharp genal spine continuing the margin smoothly. Thorax of 12 segments, pleural tips weakly spinose. Pygidium with axis of four 
rings plus small terminus finishing forward of posterior margin; pleurae with well-impressed pleural furrows; border not defined. Very fine tubercular ornament on exoskeleton, most prominent as pair of tubercles on each pygidial ring symmetrical about sagittal line.

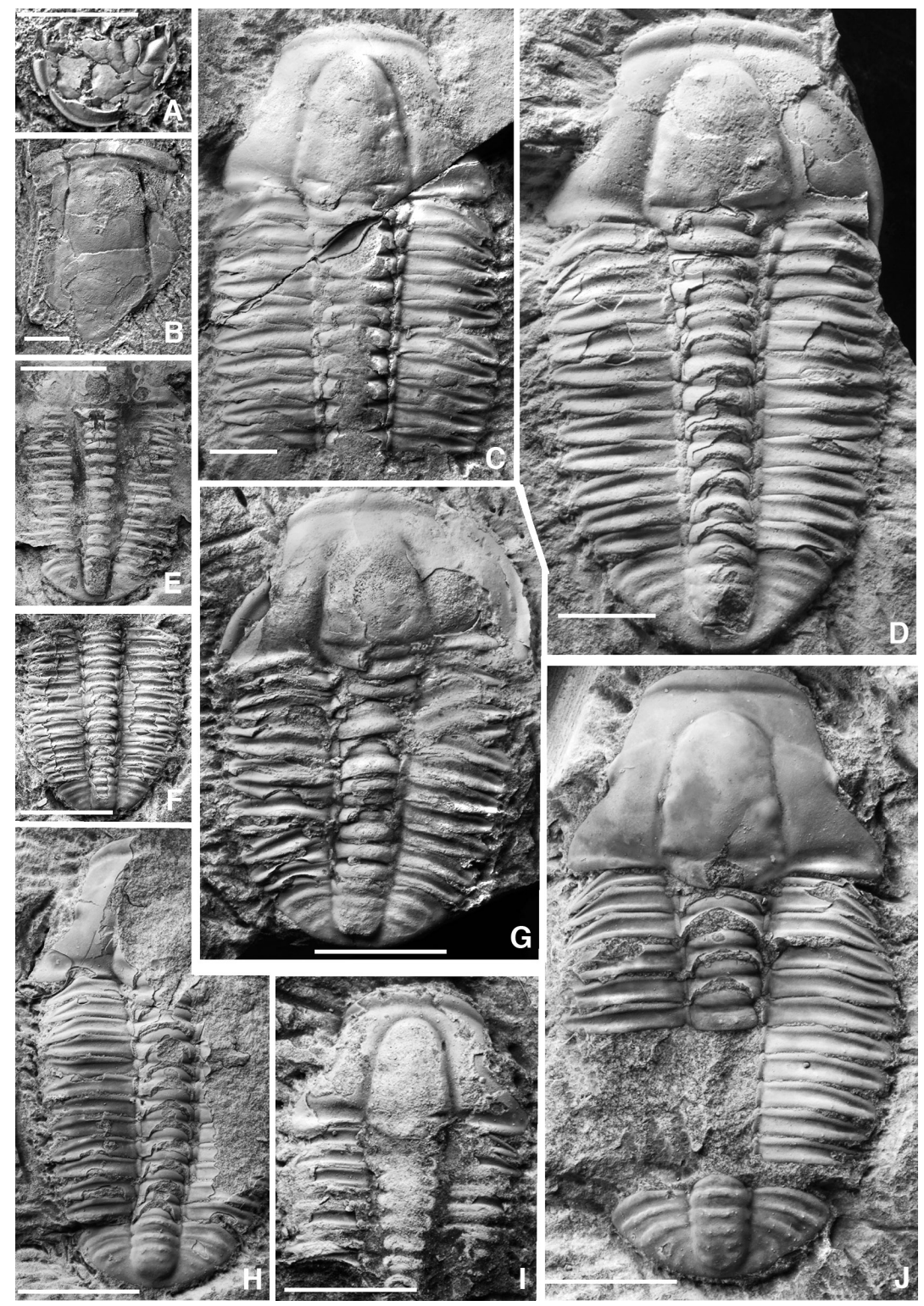

FIGURE 1. A, Aristaluta gutta Öpik, 1961, a bradoriid in lateral view, QMF59829. B, trilobite cranidium, Amphoton bensoni Öpik, 1961, QMF59830. C-J, Modocia priva sp. nov. C, QMF59831, large cranidium with incomplete thorax of 10 segments attached. D, QMF59832, holotype, exoskeleton missing left librigena. E, QMF59833, damaged exoskeleton showing thorax of 12 segments and transverse pygidium. F, QMF59834, thorax of 12 segments plus pygidium. G, QMF59835, exoskeleton with thorax partially dissociated and foreshortened. H, QMF59836, exoskeleton with damaged cranidium. I, QMF59837, poorly preserved cranidium with partial thorax attached. J, QMF59838, exoskeleton with damaged thorax. Scale bars in A, E, F, H, I = 5 mm; in B-D, G, J = $10 \mathrm{~mm}$. 
Description. Exoskeleton up to $35 \mathrm{~mm}$ long and $20 \mathrm{~mm}$ wide, moderately convex; cephalon about $30 \%$ overall length; pygidium less than $20 \%$ overall length; thorax of 12 segments. Exoskeletal surface smooth to very sparsely and finely tuberculate, more so on the pygidium.

Cranidium up to $13 \mathrm{~mm}$ long, $20 \mathrm{~mm}$ wide at rear and $13 \mathrm{~mm}$ across palpebral lobes. Anterior margin semicircular, evenly curved, with short genal spine continuing the curve; posterior margin straight. Glabella moderately convex, conical, with rounded anterior; axial furrows well impressed, straight and converging along sides of posterior half of glabella, then converging and curving forward into a rounded curve across the sagittal axis. Glabellar furrows in three pairs, very weakly impressed on external surface and absent on internal mould. Preglabellar furrow shallowing slightly across axis. Occipital ring mostly broken in available specimens; one (Figure 1I) shows a low medio-posterior tubercle and convex posterior margin. Occipital furrow transverse, shallowing across axis. Preglabellar field approximately equal in length to anterior border, gently downsloping to well-impressed border furrow. Anterior border on cranidium convex, of uniform length anterior to glabella but traversed by facial suture at low angle so that it tapers laterally to point where the facial suture turns sharply at posterior of the border. Ocular ridge weakly developed, very gently curved to anterior of palpebral lobe. Palpebral lobe short, narrow, situated forward of the glabellar mid-length, only very weakly upturned, poorly defined by shallow palpebral furrow. Anterior branch of facial suture slightly convergent to back of the anterior border, then strongly convergent across anterior border to reach margin where an anterior projection of the axial furrows would reach the margin (interpreted as indicating lateral extent of rostral plate). Posterior branch of facial suture sigmoidal, diverging weakly laterally; posterolateral limb long, narrow, downsloping lateral to fulcral point. Prominent fulcrum at posterior margin halfway between axial furrow and facial suture.

Librigena up to $5 \mathrm{~mm}$ wide, lateral margin curved and downward. Genal field gently convex. Border gently convex, of uniform width except anteriorly where the course of the facial suture across the anterior border produces a strong taper to a point in the librigenal border. Border furrow shallower than on cranidium.

Pygidium up to $8 \mathrm{~mm}$ long and $12 \mathrm{~mm}$ wide, subelliptical, moderately convex, with prominent anterior articulating half ring; anterior margin transverse from axial furrows to fulcral points, then curving weakly posteriorly lateral to the fulcral points; lateral and posterior margins in an even curve; border furrow and border not evident. Axis of four rings plus terminus no longer than each ring but reaching close to posterior margin, with pair of more prominent tubercles on each ring forming exsagittal column. Pleurae with three clear segments bearing distinct pleural furrows separated by interpleural indication, more by change of slope than by a furrow.
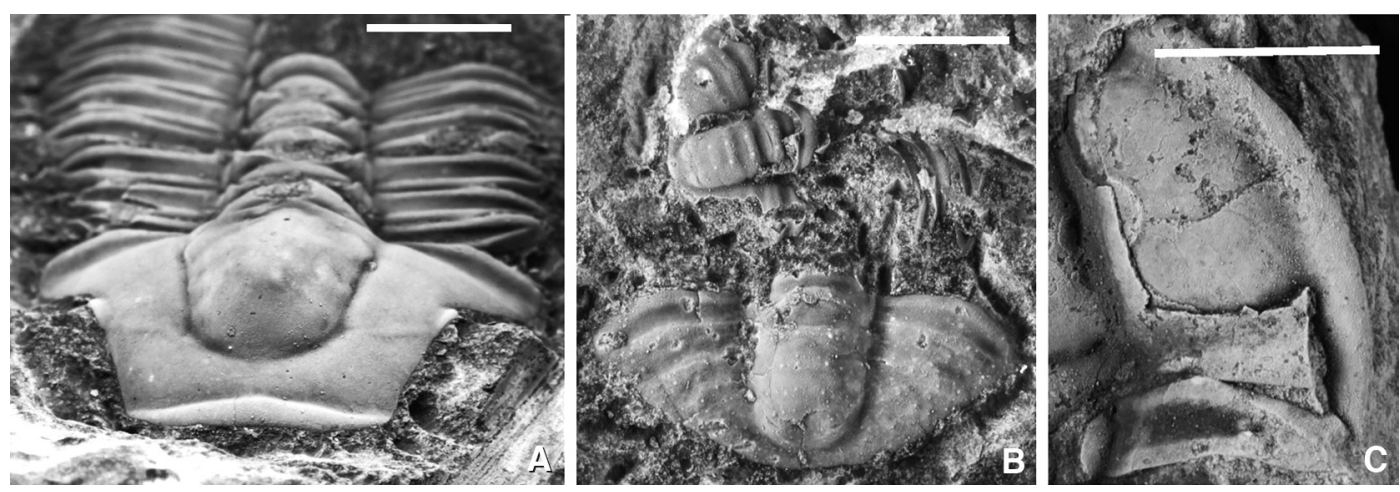

FIGURE 2. Modocia priva sp. nov. A, QMF59838, anterior view showing the moderate convexity of the cranidium. B, on back of QMF59838b, pygidia showing fine sparse tubercles. C, QMF59832, holotype, enlargement of right librigena showing continuous curve of margin onto the genal spine. Scale bars $=5 \mathrm{~mm}$. 
Comparison. Modocia priva sp. nov. is morphologically similar to several genera/species of the solenopleurid complex. One of the few demonstrably distinctive features of $M$. priva is its 12 thoracic segments. Species for which the full thorax is known are relatively few, and species with 12 segments could be considered rare; those I have been able to find are in three different genera, none of which is Solenopleura. They are Cambroproteus lemdadensis Geyer, 2015 from the Ornamentaspis frequens Zone (early middle Cambrian) of the Jbel Wawrmast Formation, in the western High Atlas Mountains, Morocco; Nilegna sigmata Öpik, 1967 from the Glyptagnostus stolidotus Zone, Georgina Limestone, western Queensland; Modocia whiteleyi Robison \& Babcock, 2011 from the Cedaria Zone in the upper Weeks Formation, Utah; and Modocia immodulata Öpik, 1967 from middle-upper Cambrian passage Zone, Steamboat Sandstone, western Queensland. Nilegna sigmata has larger, more posteriorly placed palpebral lobes, closely spaced tubercular ornament, small, laterally deflected genal spines, wider interocular cheeks and short, falcate, pointed pleural tips in the thorax, all of which distinguish it from M. priva. The superficial similarity, in number of thoracic segments, very low convexity, glabellar shape and small palpebral lobes between the early middle Cambrian $C$. lemdadensis from Morocco and the early late Cambrian M. immodulata from Australia, exemplifies precisely the pitfall warned against by Rasetti (1972, p. 43). No relationship is inferred herein, except to note that they are among the rare species of Solenopleuridae with 12 thoracic segments. Modocia whiteleyi from Utah is temporally closer to $M$. priva, being from the Cedaria Zone younger in the Guzhangian, but it has much longer eyes set closer to the glabella and to the posterior, anterior limbs of the facial suture diverging forward, cephalic border furrow not impressed, quite different thoracic pleural furrows and broad re-entrant in the posterior pygidial margin. Modocia priva sp. nov. is similar to the only slightly younger (one zone) M. immodulata that occurs about $100 \mathrm{~km}$ to the south-west. However, Öpik (1967, p. 189) diagnosed his species as "a species without glabellar furrows, without ocular ridges, distinguished by its brim [preglabellar field] being longer than the rim [border], and by its subtriangular pygidium with weak pleural furrows". Modocia priva has glabellar furrows, ocular ridges, its preglabellar field slightly shorter (sag.) than its border and transverse pygidium with well-impressed pleural furrows, so separating it at the species level. However, it would be difficult to justify separating them into different genera. Öpik (1967) only tentatively assigned immodulata to Modocia, and I here make assignment of priva similarly tentative. It is conceivable that if accurate generic discriminators are established, as so earnestly desired by most who have worked on solenopleurid and ptychopariid trilobites, these two Australian species may belong to an east Gondwanan genus, for which one discriminator may be possession of 12 thoracic segments.

Valid argument could be made for inclusion of the new species in a number of Acado-Baltic genera assigned to the Solenopleuridae based on comparison with particular species assigned across those several different genera. Solenopleura? applanata (Salter in Salter \& Hicks, 1869) of Weidner \& Nielsen (2015, fig. 50) from the Ptychagnostus atavus Zone on Bornholm, similarly dated Jincella applanata (Salter in Salter \& Hicks, 1869) of Fletcher (2006, pl.34. fig. 36), Brunswickia (Jincella) applanata of Fletcher (2007, fig. 7C-G) from the Manuels River Formation, Newfoundland in the "Paradoxides hicksii" Zone (=Ptychagnostus atavus Zone) and the two Siberian species of similar age, figured by Fletcher (2007, fig. 7I, J) are close in their short eyes, situated well forward, preglabellar field and anterior border of similar length, glabellar shape and pygidial features, but they have slightly wider fixigenae (cf. glabellar width) and curved facial sutures - but are these generic discriminators? Moreover, the significance of the temporal disparity is not yet understood; are these atavus Zone species long-ranging into the Lejopyge laevigata Zone or is it a case of convergent evolution well separated in time? Parasolenopleura scanica Westergård, 1953, pl. 6, figs 5, 6 from the Ptychagnostus gibbus Zone in Sweden is very close, differing, perhaps, only in the slightly longer preglabellar field (sag.) and smaller, more transverse pygidium. Brunswickia robbii (Hartt in Dawson, 1868) from the early middle Cambrian Eccaparadoxides eteminicus Zone in New Brunswick, Canada (Fletcher, 2005) 
is very similar in cranidial features despite the wide separation both temporally and geographically; only the length of the anterior border remaining uniform farther laterally, lack of glabellar furrows and more prominent eye ridges providing any morphological separation, and that could hardly be considered generically significant.

\section{Other Australian Solenopleuridae}

Despite the uncertainties of familial and generic placement of this new species, its overall morphology resembles most closely the Solenopleuridae. The new species is readily recognised as a standard ptychoparioid of the large complex of genera spread through the Solenopleuridae and Ptychopariidae and several families derived therefrom. Since no comparative marjumiids have been reported in Australia, a survey of Australian solenopleurids is provided here. Solenopleurid trilobites were first suggested as occurring in Australia by Kobayashi $(1935$, p. 265) who assigned early Cambrian Conocephalites australis Woodward, 1884 (Etheridge, 1898, 1919) and the synonymous Ptychoparia howchini Etheridge, 1898, to Solenopleura. Kobayashi (1942, p. 492) later recognised his error and designated $C$. australis as type species of a new genus, Yorkella (see Jell in Bengtson et al., 1990, p. 288).

Whitehouse (1939) erected Asthenopsis as a member of the Solenopleuridae; an action supported by Harrington et al. (1959, p. 275) and
Öpik (1956, p. 19) who listed it as a subgenus of Solenopleura. Öpik (1967, p. 184) suggested that Asthenopsis could belong to either Solenopleuridae or Ptychopariidae, and Jell (1978) provided support for Ptychopariidae by introducing several species with glabellar anteriors more truncated than the conical shape in Solenopleuridae.

Solenopleura? erista Öpik, 1967 remains a questionable generic assignment, but nevertheless the only existing Australian taxon with this generic epithet. Nilegna Öpik 1967 (with type and only species N. sigmata Öpik, 1967) and Modocia? immodulata Öpik, 1967 were also described as western Queensland members of the Solenopleuridae.

In describing the solenopleurid Changqingia chalcon (Walcott, 1911) (as Austrosinia chalcon), Zhang \& Jell (1987, pl. 40, figs 12-15) figured a cranidium and two pygidia of that species from a Ptychagnostus punctuosus Zone horizon in the Currant Bush Formation, $10 \mathrm{~km}$ west of Thorntonia station, northwestern Queensland. That pygidium is entirely different from that of the new species described above.

Solenopleuridae, gen. et sp. indet. of Jago (1980, pl. 1, figs 10-16) and Menocephalites (?) sp. of Jago \& McNeill (1997, pl. 1, figs C, E, F) define the family's presence in Tasmania, but despite only dissociated exoskeletal elements being available, both taxa may be recognised as quite distinct from the species described above.

\section{Acknowledgements}

I am grateful to Alex Cook for assistance in the field and to Jim Jago and Terry Fletcher for their constructive reviews of this paper.

\section{Literature Cited}

Angelin, N. P. (1851-1878). Palaeontologia Scandinavica. Pars 1. Crustacea Formationis Transitionis [fasc. 1 (1851): Palaeontologia Suecica, 1-24; fasc. 2 (1854): Palaeontologia Scandinavica 21-92]. Academiae Regiae Scientarum Suecanae. [republished in combined and revised form in 1878 with Lindström, G., ed. Norstedt \& Söner].

Bengtson, S., Conway Morris, S., Cooper, B. J., Jell, P. A., \& Runnegar, B. N. (1990). Early Cambrian fossils from South Australia. Memoirs of the Association of Australasian Palaeontologists, 9, 1-364.

Cooper, R. A., Begg, J. G., \& Bradshaw, J. D. (1990). Cambrian trilobites from Reilly Ridge, northern Victoria Land, Antarctica, and their stratigraphic implications. New Zealand Journal of Geology and Geophysics, 33, 55-66. https://doi.org/10.1080/00288306.1990.10427573

Dawson, J. W. (1868). Acadian Geology: The Geological Structure. Organic Remains and Mineral Resources of Nova Scotia, New Brunswick, and Prince Edward Island (2nd ed.). Macmillan. https:// doi.org/10.5962/bhl.title.38560 
Emmrich, H. F. (1839). De trilobitis. Disertatio petrofactologica. Berolini. https://doi.org/10.5962/bhl. title. 9665

Etheridge, R. Jr (1898). A further Cambrian trilobite from the Yorke Peninsula. Transactions of the Royal Society of South Australia, 22, 1-3.

Etheridge, R. Jr. (1919). The Cambrian trilobites of Australia and Tasmania. Transactions of the Royal Society of South Australia, 43, 373-393.

Fletcher, T. P. (2005). Holaspid variation in the solenopleurid trilobite Parasolenopleura gregaria (Billings, 1865) from the Cambrian of Newfoundland. Palaeontology, 48, 1075-1089. https://doi. org/10.1111/j.1475-4983.2005.00494.x

Fletcher, T. P. (2006). Bedrock geology of the Cape St. Mary's Peninsula, southwest Avalon Peninsula, Newfoundland (includes parts of NTS map sheets 1M/1, 1N/4, 1L/16 and 1K/13), Newfoundland. Government of Newfoundland and Labrador, Geological Survey, Department of Natural Resources, St. John's, Report, 06-02, 1-117.

Fletcher, T. P. (2007). Correlating the zones of 'Paradoxides hicksii' and 'Paradoxides davidis' in Cambrian Series 3. Memoirs of the Association of Australasian Palaeontologists, 33, 35-56.

Fletcher, T. P. (2017). Agraulos ceticephalus and other Cambrian trilobites in the subfamily Agraulinae from Bohemia, Newfoundland and Wales. Papers in Palaeontology, 3, 175-217. https://doi.org/10.1002/ spp2.1071

Fortey, R. A. (1997). The problem of the Ptychopariina. In R. L. Kaesler (Ed.), Treatise on Invertebrate Paleontology, Part O Arthropoda 1, Trilobita, Revised (pp. 295-297). The Geological Society of America, Inc. and The University of Kansas Press. https://doi.org/10.17161/dt.v0i0.5613

Geyer, G. (2015). Exotic trilobites from the Lower-Middle Cambrian boundary interval in Morocco and their bearing on the Cambrian Series 3 lower boundary. Paläontologie Zeitschrifte, 89, 749-781. http://doi.org/10.1007/s12542-014-0254-0

Geyer, G. (2019). A comprehensive Cambrian correlation chart. Episodes, 42, 321-332. https://doi. org/10.18814/epiiugs/2019/019026

Harrington, H. J., Henningsmoen, G., Howell, B. F., Jaanusson, V., Lochman-Balk, C., Moore, R. C., Poulsen, C., Rasetti, F., Richter, E., Richter, R., Schmidt, H., Sdzuy, K., Struve, W., Tripp, R., Weller, J. M., \& Whittington, H. B. (1959). Systematic descriptions. In R. C. Moore (Ed.), Treatise on Invertebrate Paleontology, Part O, Arthropoda 1. (pp. O170-O540). Geological Society of America and University of Kansas Press.

Howell, B. F. (1937). Cambrian Centropleura vermontensis fauna of northwestern Vermont. Geological Society of America Bulletin, 48, 1147-1210. https://doi.org/10.1130/gsab-48-1147

Jago, J. B. (1980). Late Middle Cambrian fossils from Beaconsfield, Tasmania. Papers and Proceedings of the Royal Society of Tasmania, 114, 219-223. https://doi.org/10.26749/rstpp.114.219

Jago, J. B., \& McNeill, A. W. (1997). A late Middle Cambrian shallow-water trilobite fauna from the Mt Read Volcanics, northwestern Tasmania. Papers and Proceedings of the Royal Society of Tasmania, 131, 85-90. https://doi.org/10.26749/rstpp.131.85

Jell, P. A. (1978). Asthenopsis Whitehouse, 1939 (Trilobita, Middle Cambrian) in northern Australia. Memoirs of the Queensland Museum, 18, 219-231.

Kobayashi, T. (1935). The Cambro-Ordovician formations and faunas of south Chosen. Palaeontology. Part 3. Cambrian faunas of south Chosen with a special study on Cambrian trilobite genera and families. Journal of the Faculty of Science Tokyo University, Section 2: Geology, 4, 49-344.

Kobayashi, T. (1942). Two Cambrian trilobites from the Parara Limestone in the Yorke's Peninsula, South Australia. Proceedings of the Imperial Academy, Tokyo, 18, 492-498. https://doi.org/10.2183/ pjab1912.18.492

Lochman, C., \& Duncan, D. (1944). Early Upper Cambrian faunas of central Montana. Geological Society of America Special Papers, 54, 1-181. https://doi.org/10.1130/spe54-p1 
Matthew, G. F. (1888). Illustrations of the fauna of the St. John Group. II. The smaller trilobites with eyes (Ptychoparidae and Ellipsocephalidae). Transactions of the Royal Society of Canada 5(4), 123-166.

Meek, F. B., \& Hayden, F. V. (1861). Descriptions of new Lower Silurian (Primordial), Jurassic, Cretaceous, and Tertiary fossils collected in Nebraska Territory. Proceedings of the Academy of Natural Sciences of Philadelphia, 5, 415-447.

Öpik, A. A. (1956). Cambrian geology of Queensland. Bureau of Mineral Resources Geology and Geophysics Australia Bulletin, 49, 1-24.

Öpik, A. A. (1961). The geology and palaeontology of the headwaters of the Burke River, Queensland. Bureau of Mineral Resources Geology and Geophysics Australia Bulletin, 53, 1-249.

Öpik, A. A. (1967). The Mindyallan fauna of north-western Queensland. Bureau of Mineral Resources Geology and Geophysics Australia Bulletin, 74, 1-404.

Peng, S. C, Babcock, L. E., Zuo, J. X., Lin, H. L., Zhu, X. J., Yang, X. F., Robison, R. A., Qi, Y. P., Bagnoli, G., \& Chen, Y. A. (2009). The Global Boundary Stratotype Section and Point (GSSP) of the Guzhangian Stage (Cambrian) in the Wuling Mountains, Northwestern Hunan, China. Episodes, 32, 41-55. https://doi.org/10.18814/epiiugs/2009/v32i1/006

Palmer, A. R. (1954). The faunas of the Riley Formation in central Texas. Journal of Paleontology, 28, 709-786.

Rasetti, F. (1948). Lower Cambrian trilobites from the conglomerates of Quebec (exclusive of the Ptychopariidea). Journal of Paleontology, 22, 1-29.

Rasetti, F. (1963). Middle Cambrian ptychoparioid trilobites from the conglomerates of Quebec. Journal of Paleontology, 37, 575-594.

Rasetti, F. (1965). Upper Cambrian trilobite faunas of northeastern Tennessee. Smithsonian Miscellaneous Collections, 148(3), 1-127.

Rasetti, F. (1972). Cambrian trilobite faunas of Sardinia. Atti della Accademia Nazionale dei Lincei Memorie, Classe di Scienze fisiche, matematiche e naturali, Series, 8, 11, 1-100.

Robison, R. A. (1964). Late Middle Cambrian faunas from western Utah. Journal of Paleontology, 38, $510-566$.

Robison, R. A. (1988). Trilobites of the Holm Dal Formation (late Middle Cambrian), central North Greenland. Meddelelser фm Grønland, Geoscience, 20, 23-103.

Robison, R. A., \& Babcock, L. E. (2011). Systematics, paleobiology, and taphonomy of some exceptionally preserved trilobites from Cambrian Lagerstätten of Utah. Paleontological Contributions from The University of Kansas, Paleontological Institute, 5, 1-47. https://doi.org/10.17161/PC.1808.8543

Rushton, A. W. A. (1978). Fossils from the Middle-Upper Cambrian transition in the Nuneaton district. Palaeontology, 21, 245-283.

Rushton, A. W. A., \& Berg-Madsen, V.(2002). The age of the Middle Cambrian 'Paradoxidesforschammeri Grit' of the Wrekin district, Shropshire, England. Transactions of the Royal Society of Edinburgh: Earth Sciences, 92, 335-346. http://doi.org/10.1017/S0263593300000274

Salter, J. W., \& Hicks, H. (1869). On some fossils from the "Menevian Group". Quarterly Journal of the Geological Society of London, 25, 51-57. https://doi.org/10.1144/gsl.jgs.1868.024.01-02.61

Šnajdr, M. (1957). O nových trilobitech z českého Kambria. Vëstník Ústř̌edního Ústavu Geologického, 32, 235-244.

Šnajdr, M. (1958). Trilobiti českého středního Kambria. Rozpravy Ústředního Ústavu Geologického, 24, $1-289$.

Sundberg, F. A. (1996). Morphological diversification of Ptychopariida (Trilobita) from the Marjumiid Biomere (Middle and Upper Cambrian). Paleobiology, 22, 49-65. https://doi.org/10.1017/ s0094837300016018

Swinnerton, H. H. (1915). Suggestions for a revised classification of trilobites. Geological Magazine (new series), 6(2), 487-496 and 538-545. http://doi.org/10.1017/S0016756800203737

Walcott, C. D. (1911). Cambrian faunas of China. Smithsonian Miscellaneous Collections, 57, 69-108. 
Walcott, C. D. (1916). Cambrian trilobites. Smithsonian Miscellaneous Collections, 64, 303-457.

Walcott, C. D. (1924). Cambrian and Lower Ozarkian trilobites. Smithsonian Miscellaneous Collections, $75,53-60$.

Walcott, C. D. (1925). Cambrian and Ozarkian trilobites. Smithsonian Miscellaneous Collections, 75, 61-146.

Weidner, T., \& Nielsen, A. (2014). A highly diverse trilobite fauna with Avalonian affinities from the Middle Cambrian Acidusus atavus Zone (Drumian Stage) of Bornholm, Denmark. Journal of Systematic Palaeontology, 12, 23-92. http://doi.org/10.1080/14772019.2012.740080

Westergård, A. H. (1946). Agnostidea of the Middle Cambrian of Sweden. Sveriges Geologiska Undersökning, Series C, 477, 40(1), 1-140.

Westergård, A. H. (1953). Non-agnostidean trilobites of the Middle Cambrian of Sweden, III. Sveriges Geologiska Undersökning, Series C, 525, 46(2), 1-58.

Wheeler, R. R. (1942). New mid-Cambrian ptychopariid. American Journal of Science, 240, 567-570.

Whitehouse, F. W. (1939). The Cambrian faunas of north-eastern Australia. Memoirs of the Queensland Museum, 11, 179-282.

Woodward, H. (1884). Note on the remains of trilobites from South Australia. Geological Magazine, decade 3, 1, 372-374. https://doi.org/10.1017/s0016756800164994

Zhang, W. T., \& Jell, P. A. (1987). Cambrian trilobites of north China - Chinese Cambrian trilobites housed in the Smithsonian Institution. Science Press.

\section{Author Profile}

Peter A. Jell is an Adjunct Professor of The University of Queensland and a Research Associate of the Queensland Museum. He is a former Curator and Deputy Director, Scientific and Collections of the Queensland Museum with 50 years' experience studying the Cambrian faunas of northwestern Queensland. He has written more than 20 publications directly concerning the Cambrian of Queensland, with a large paper on Cambrian echinoderms, currently in press. Most prominent was his editorship of and contributions to the landmark 2012 book, Geology of Queensland. 
